\title{
JUIZ, AGENTE POLÍTICO OU SERVIDOR PÚBLICO? ANÁLISE CRÍTICA DA NATUREZA JURÍDICA DA FUNÇÃO JURISDICIONAL A PARTIR DO CONSTITUCIONALISMO MODERNO E DO ATIVISMO JUDICIAL
}

\author{
JUDGE, POLITICAL AGENT OR PUBLIC SERVANT? \\ CRITICAL ANALYSIS OF THE LEGAL NATURE OF THE \\ JURISDICTIONAL FUNCTION FROM MODERN \\ CONSTITUTIONALISM AAND JUDICIAL ACTIVISM
}

\author{
${ }^{1}$ Thalyany Alves Leite \\ 2 Vicente Bandeira de Aquino Neto
}

\section{RESUMO}

$\mathrm{O}$ artigo desenvolve estudo sobre a natureza da função desempenhada pelo magistrado, no sentido de verificar se ele é um servidor público, como defende parte da doutrina, ou se ele é um agente político - tese defendida pelo Supremo Tribunal Federal e pelo presente trabalho. Para avaliar a natureza jurídica da função do juiz, o trabalho realizou resgate histórico do constitucionalismo moderno. Empós, deteve-se a análise de dois movimentos potencializados pela Constituição Federal de 1988, quais sejam, a judicialização e o ativismo judicial. Ao final, apontou-se que a função do magistrado no exercício de suas atividades tem caráter eminentemente político.

PALAVRAS-CHAVE: Função Jurisdicional; Judicialização; Ativismo Judicial; Juiz como agente político; Constitucionalismo

\begin{abstract}
The article develops a study of the function performed by the magistrate, in order to verify if he is a public servant, or if he is a political agent - defended by the Federal Supreme Court and the present work. In order to evaluate the legal nature of the judge's function, the work carried out a historical rescue of modern constitutionalism. After, the analysis of two movements strengthened by the Federal Constitution of 1988, judicialization and judicial activism. In the end, it was pointed that the function of the magistrate in the exercise of his activities has eminently political character.
\end{abstract}

KEYWORDS: Jurisdictional Function; Judiciary; Judicial ; Judge as political agente; Constitutionalism

\footnotetext{
${ }^{1}$ Doutoranda em Direito Constitucional pela Universidade de Fortaleza - UNIFOR, Ceará, CE, (Brasil). Mestre em Direito Constitucional pela Universidade de Fortaleza - UNIFOR, Ceará, CE, (Brasil). Advogada. E-mail: thalyany@yahoo.com.br.

${ }^{2}$ Doutorando em Direito Constitucional pela Universidade de Fortaleza. Mestre em Direito Constitucional pela Universidade de Fortaleza - UNIFOR, Ceará, CE, (Brasil). Advogado Eleitoral. E-mail:
} 


\section{INTRODUÇÃO}

Resgatando a teoria clássica amplamente difundida da tripartição dos poderes, pensada originalmente por Montesquieu, no sistema de checks and balances, o Estado desenvolve três macro funções por intermédio de seus agentes e de suas instituições: executiva, legislativa e judicante. Hoje, para uma consolidação do Estado de Direito, inaugurado pela Constituição Federal de 1988, é preciso, de fato, que esses poderes interajam harmonicamente. Entretanto, principalmente nos últimos tempos, mesmo em face da dinâmica das relações sociais, o Poder Judiciário tem ganhado maior força e notoriedade por ter se imiscuído, muitas vezes, nas ações de caráter eminentemente executivo e legislativo.

Note-se, por exemplo, a amplo espaço midiático dedicado ao Poder Judiciário, no julgamento de casos como mensalão, operação lava jato, aborto de fetos anencéfalos e reconhecimento de uniões homoafetivas. Isso demonstra que o Judiciário possui uma credibilidade crescente dentro do cenário político brasileiro, que pode ser justificada pelo fato desta função do poder ter assumido uma posição ativista, proferindo decisões que afetam, direta ou indiretamente, todos os brasileiros, chegando, inclusive a interferir no campo do Legislativo e do Executivo, bem como a crise institucional que atinge estes.

A partir desse contexto, é de se questionar o que levou o Poder Judiciário a assumir uma posição central no atual cenário político brasileiro. Ademais, é importante identificar se o Judiciário possui uma posição ativista, bem como se o juiz é um agente político ou um servidor público, como dispõe a doutrina administrativa clássica.

Para responder esses questionamentos, o trabalho, o qual possui como objetivo central demonstrar a real natureza do magistrado dentro da administração pública, foi dividido em três capítulos. O primeiro faz uma análise da evolução do constitucionalismo moderno, detendo-se a referida análise a dois momentos importantes na história do Direito Constitucional: a Revolução Francesa e a independência dos Estados Unidos, consideradas a base do constitucionalismo. Deve-se ressaltar que é reconhecida a importância da história da Inglaterra no estudo do Direito Constitucional. Contudo, pelo fato de não se defender, ali, a Supremacia da Constituição concluiu-se que não ser imprescindível o enfrentamento do tema para a presente pesquisa.

Depois, dar-se-á ênfase a dois movimentos crescentes no Brasil: a judicialização e o ativismo judicial. Serão apresentados os conceitos de cada um dos referidos fenômenos, bem como os fatores que permitem que os juízes possam sempre reconhecer causas que deveriam Revista de Teorias da Democracia e Direitos Políticos le-SSN: 2525-9660| Curitiba | v. 2 | n. 2 | p. 76 - $97 \mid$ 
Juiz, Agente Político ou Servidor Público? Análise Crítica da Natureza Jurídica da Função Jurisdicional a Partir do Constitucionalismo Moderno e do

Ativismo Judicial

ser resolvidas nas outras esferas do Poder, bem como a permissão de proferir decisões de cunho político.

Em arremate, com base no que foi exposto nos dois primeiros capítulos, será defendida a posição de que o magistrado é um agente político. Para isso, será confrontada a doutrina que defende a clássica ideia de que o juiz é um mero agente público como a posição do Supremo Tribunal Federal e de outra parte da doutrina que afirma que o juiz é um agente político.

Relativamente aos aspectos metodológicos, no presente trabalho foi utilizado o método dialético com predominância indutiva, utilizando-se de procedimento histórico. Como técnicas de pesquisa, foram utilizados meios bibliográficos (livros, jornais, artigos científicos), bem como pesquisa de jurisprudência do Supremo Tribunal Federal.

\section{A NOVA FACE DO CONSTITUCIONALISMO: ASPECTOS HiSTÓRICOS E CONCEITUAIS DO NEOCONSTITUCIONALISMO}

O assunto principal desse trabalho é o exame do ativismo judicial e suas implicações na atual realidade brasileira. Porém, não se pode analisá-lo sem ter a compreensão do contexto que a gerou. Por isso, a importância de entender o conceito e as características do neoconstitucionalismo, fenômeno que ganha destaque no estudo do Direito Constitucional brasileiro, principalmente depois da promulgação da Constituição Federal de 1988, que trouxe o real conceito de supremacia, normatividade e centralidade da Constituição.

As três características relacionadas são decorrentes do desenvolvimento e da declaração dos Direitos Fundamentais, que, para serem observados, necessitavam estar localizados em um diploma que tivesse força suficiente para fazer com que todo o ordenamento jurídico o seguisse e o respeitasse. Este diploma é a Constituição que nem sempre esteve no patamar mais elevado da estrutura sistêmica do ordenamento jurídico brasileiro.

\subsection{Histórico do Constitucionalismo}

Antes de ser iniciada a análise do neoconstitucionalismo, faz-se necessário analisar a evolução constitucional. Para isso, essa parte do trabalho será dividida em dois momentos. O primeiro mostrará como foi que se deu a referida evolução na Europa, com foco na Revolução Francesa, e nos Estados Unidos; e, por fim, mostrar-se-á como se deu o desenvolvimento do 
constitucionalismo brasileiro, o qual pode ser dividido em duas fases: pré e pós Constituição de 1988.

Como se pode perceber, em nenhum momento foi citado o modelo inglês de constitucionalidade. Isso se deve ao fato dele não se adequar à realidade brasileira, porquanto as normas constitucionais inglesas, materialmente falando, baseiam-se nos costumes, além de não possuir uma Constituição escrita. ${ }^{3}$ Deve-se, outrossim, frisar que na Inglaterra não há a Supremacia da Constituição, mas Supremacia do Parlamento, o que impossibilita, destarte, o controle de constitucionalidade. (Sarlet; Marinoni; Mitidiero, 2012, p. 43)

\subsubsection{Evolução do modelo constitucional da França e dos Estados Unidos}

Ao consultar a doutrina acerca da origem do movimento constitucionalista, ${ }^{4}$ percebese que há uma discussão em relação ao momento de sua origem. Alguns autores ${ }^{5}$ afirmam em suas obras que a gênese do constitucionalismo vem da Idade Antiga, fazendo advertência aos leitores do equívoco que é a suposição de que o referido movimento surgiu a partir da Idade Moderna. ${ }^{6}$ Como não é o intuito deste trabalho fazer um apanhado histórico de todo o movimento constitucionalista, ter-se-á, como ponto de partida, a Revolução Francesa, devido a sua grande importância no constitucionalismo moderno.

A França, no final do século XVIII, vivia em uma intensa crise. O governo absolutista, o qual tinha como essência a concentração do poder nas mãos de uma única pessoa, o Rei, estava em crescente declínio, devido às decisões arbitrárias, que trouxeram

\footnotetext{
${ }^{3}$ Frisa-se que é totalmente equivocada a afirmação de que a Inglaterra nunca possuiu uma Constituição escrita. O referido país, ainda que marcado pelo seu caráter efêmero, teve um documento que é considerado uma Constituição, conforme Ingo Wolfgang Sarlet, o qual afirma que depois de "[...] instaurada a República, o comandante do exército que derrotou as forças monárquicas, Oliver Cromwell, dissolveu o Parlamento (1652) e iniciou uma espécie de absolutismo (ou ditadura) republicana, além de promulgar um documento que costuma ser considerado com a primeira versão de uma espécie de constituição escrita, que, tal como já apontado na parte introdutória, foi única que a Inglaterra jamais teve (o assim chamado Instrumento of Government, de 1653) e que esteve em vigor por pouco tempo, tendo em vista a morte de Cromwell (1658) e a restauração da Monarquia, em 1660, com o retorno do exílio de Carlos II, filho de Carlos I". (SARLET, Ingo Wolfgang; MARINONI, Luiz Guilherme; MITIDIERO, Daniel. Curso de Direito Constitucional. São Paulo: Revista dos Tribunais, 2012, p. 40-41.)

${ }^{4}$ Nesse momento, o movimento constitucionalista está no sentido material do termo, ou seja, conjunto de normas destinadas a organizar a sociedade política.

5 André Ramos Tavares, no seu Curso de Direito Constitucional, apresenta o desenvolvimento do Constitucionalismo desde a Idade Antiga, passando pela Idade Média, até chegar a Idade Moderna com o conceito do Direito Constitucional Contemporâneo (TAVARES, André Ramos. Curso de Direito Constitucional. 9. ed. São Paulo: Saraiva, 2011, p. 25 e ss.). Além desse autor, também é mister citar a obra de Manoel Gonçalves Ferreira Filho, o qual faz um breve apanhado histórico, apresentando a evolução do constitucionalismo (FERREIRA FILHO, Manoel Gonçalves. Curso de Direito Constitucional. 36. ed. São Paulo: Saraiva, 2010, p. 29 e ss.).

6 "É errôneo supor que o constitucionalismo surgiu apenas com o advento das revoluções modernas, que instauraram a democracia e afastaram os regimes absolutistas até então existentes". (TAVARES, André Ramos. Curso de Direito Constitucional. 9. ed. São Paulo: Saraiva, 2011, p. 25.)

Revista de Teorias da Democracia e Direitos Políticos le-SSN: 2525-9660| Curitiba | v. 2 | n. 2 | p. 76 - $97 \mid$
} 
Juiz, Agente Político ou Servidor Público? Análise Crítica da Natureza Jurídica da Função Jurisdicional a Partir do Constitucionalismo Moderno e do

Ativismo Judicial

prejuízos ao país. A população, cada vez mais pobre e sufocada pela crescente carga tributária, vivia em uma intensa agonia e desespero. Além disso, cada vez mais o pensamento iluminista, guiado pelo racionalismo, ganhava adeptos; ${ }^{7}$ os burgueses, que estavam vivendo em um momento de crescente poder econômico, queriam uma maior participação no cenário político. (Sarlet; Marinoni; Mitidiero, 2012, p. 38) Todos esses elementos faziam parte da receita que culminou na chamada Revolução Francesa o qual rompeu com o antigo regime e inaugurou um novo momento na história da humanidade. ${ }^{8}$

Com a ruptura do antigo regime, o poder do monarca, que era centralizado, indivisível e absoluto, caiu por terra junto com sua cabeça. Começou-se a implementar a ideia da separação dos poderes e a limitação do poder estatal, como pode ser observado no art. 16 da Declaração dos Direitos do Homem e do Cidadão, o qual dispõe que toda sociedade na qual não esteja assegurada a garantia dos direitos nem determinada a separação de poderes não possui Constituição.

A nova sociedade francesa, fundada nas ideias liberais, não tolerava a interferência do Estado nas relações privadas, preservando, ao máximo, a liberdade. Daí surge a primeira “dimensão" dos Direitos Fundamentais, o qual defendia a existência do Estado absenteísta, tendo como objetivo a proteção da propriedade e do direito de liberdade. ${ }^{9}$

Apesar de, a priori, ter ocorrido a queda do antigo regime, bem como a apresentação dos princípios da Revolução ("sociedade política fundada sobre o contrato social, de uma ordem jurídica apoiada na razão humana, de um Estado que se curvava à liberdade individual”), (Bonavides, 2010, p. 37) deve-se ressaltar que as Constituições, oriundas do

\footnotetext{
${ }^{7}$ Sobre os aspectos do iluminismo, merece destaque a assertiva de Ingo Wolfgang Sarlet: “[...] Dentre tantos outros aspectos dignos de nota, enfatiza-se aqui a afirmação do primado da lei em detrimento do costume como fonte do direito (movimento de codificação), além da alteração da concepção até então vigente de soberania como centrada na figura do príncipe, para um conceito de soberania nacional, onde a lei era concebida como a expressão máxima da vontade geral". (SARLET; MARINONI; MITIDIERO, op. cit., p. 38.)

${ }^{8}$ Fábio Konder Comparato, ao analisar a Revolução Francesa e com o objetivo de demonstrar a forte a forte intenção que os revolucionários tinham de instaurar um novo pensamento, afirma que "A convicção de fundar um mundo novo, que não sucedia o antigo, mas a ele se opunha radicalmente, levou aliás os revolucionários à destruição sem remorsos de um número colossal de monumentos históricos e obras de arte, em todo o território do reino. Para os líderes intelectuais da revolução, esses bens não apresentavam nenhum valor cultural, mas eram, bem ao contrário, contravalores". (COMPARATO, Fábio Konder. A afirmação histórica dos Direitos Humanos. 7. ed. São Paulo: Saraiva, 2010, p. 142.)

9 "Essa ideia [pensamento liberal defendido por Locke] é um reflexo claro da influência da burguesia vitoriosa, que acabara de assumir o poder político. O recado dado pela burguesia para o governante, expresso nessas declarações, era bastante direto: proteja minha propriedade (direito "sagrado e inviolável", de acordo com a declaração francesa), cumpra a lei que meus representantes aprovarem (princípio da legalidade) e não se meta em meus negócios, nem em minha vida particular, especialmente na escolha de minha religião. Eis a explicação para a consagração de inúmeros direitos de liberdade [...]". (MARMELSTEIN, George. Curso de Direitos Fundamentais. 2. ed. São Paulo: Atlas, 2009, p. 45.)
} 
pensamento liberal e amparadas pela ideia de universalidade, tinham em seus âmagos um "substrato material individualista", (Bonavides, 2010, p. 37) o que trouxe prejuízos a uma determinada parte da sociedade. Isso se deve ao fato da Constituição de uma classe (dos burgueses) se transformar "[...] pela imputação dos liberais no conceito genérico de Constituição, de todas as classes”. (Bonavides, 2010, p. 37)

Frisa-se que com a Revolução Francesa, baseada nos ideais iluministas, principalmente nos de Rousseau, criou-se o pensamento de que o povo é soberano e sua vontade é o que importa. Para que seu poder fosse expressado, o parlamento foi designado como o seu representante, não dando muita ênfase à Constituição, visto que a Supremacia do Parlamento, não é compatível com a Supremacia Constitucional. ${ }^{10}$

Além disso, é importante ressaltar que o Judiciário era visto com desconfiança pelos revolucionários. Com a Supremacia do Parlamento, o referido órgão tinha como a simples função de aplicar a lei ao caso concreto, ou seja, o juiz fazia uma mera "aplicação mecânica da lei".11

Isso, contudo, não ocorreu nos Estados Unidos, que, ao contrário da França, não teve uma quebra de paradigma tão violenta, que chegasse a alterar todos os padrões políticos vigentes, ou seja, a queda de um monarca e a surreição do povo - ou melhor, dos burgueses ao poder, devendo ser ressaltado que a promulgação da Constituição norte-americana é resultado de uma construção que levou anos para ser consolidada, pois em 1776, com a Declaração de Independência assinada, as ex-colônias inglesas se tornaram Estados independentes e soberanos. Contudo, já prevendo a retaliação por parte da Inglaterra, as antigas colônias, em 1781, se uniram e formaram uma confederação, que foi estabelecida pelos Articles of Confederation. Em 1787, com a convocação da Convenção de Filadélfia, foi estabelecido pelas integrantes da confederação, com o intuito de criar uma maior estabilidade e unidade, a promulgação da primeira e única Constituição dos Estados Unidos, com a consequente criação da federação e do presidencialismo que foi a forma encontrada pelas ex-

\footnotetext{
10 “A supremacia do Parlamento não se concilia com a ideia de supremacia da Constituição, o que decerto concorre para explicar o desinteresse dos revolucionários na Europa por instrumentos destinados a resguardar a incolumidade da ordem constitucional”. (MENDES, Gilmar Ferreira; BRANCO, Paulo Gustavo Gonet. Curso de Direito Constitucional. 6. ed. São Paulo: Saraiva, 2011, p. 53.)

11 A supremacia do Parlamento tornava impensável um controle judiciário das leis. Além disso, os revolucionários franceses devotavam especial desconfiança aos juízes, vistos como adversários potenciais da Revolução. O Judiciários era tido como órgão destinado a realizar a aplicação mecânica da lei, por meio de um silogismo, no qual a premissa maior era a lei, e a menor, os fatos, daí redundando uma conclusão única e inexorável - a decisão judicial”. (MENDES; BRANCO, op. cit., p. 53)

Revista de Teorias da Democracia e Direitos Políticos le-SSN: 2525-9660| Curitiba | v. 2 | n. 2 | p. 76 - $97 \mid$ 
Juiz, Agente Político ou Servidor Público? Análise Crítica da Natureza Jurídica da Função Jurisdicional a Partir do Constitucionalismo Moderno e do

Ativismo Judicial

colônias para estruturar e organizar internamente o poder. (Sarlet; Marinoni; Mitidiero, 2012, p. 45)

Além disso, é mister ressaltar que nos Estados Unidos, onde foi gerada a primeira Constituição no sentido moderno do termo, (Sarlet; Marinoni; Mitidiero, 2012, p. 44) foi adotada uma metodologia de estrutura normativa diferente da França. Enquanto esta, como já ressaltado, defendia a ideia de que o Parlamento, como representante do povo, era soberano e que a Constituição era um mero documento que dispunha a estrutura do Estado, naquele país ocorreu o contrário, pois o Legislativo era a função do poder que era vista com desconfiança ${ }^{12}$ pelo povo norte-americano.

Destarte, constatou-se que era necessário que a delineação dos limites das funções do poder deveriam estar localizadas em um "documento vinculante, insuscetível de ser alterado pelas mesmas maiorias contra as quais as limitações eram dispostas", (Mendes; Branco, 2011, p. 56) ou seja, os referidos limites deveriam ser blindados, evitando, assim, que o Legislativo os alterassem. Com isso, a Constituição passa a ser considerada um documento limitador dos poderes, firmando-se a ideia de sua superioridade dentro do ordenamento.

Ora, se a Constituição é um documento que está no topo do ordenamento jurídico e, destarte, vincula todos os outros atos normativos e limita poderes, é lógico que, em algum momento, haveria a criação de algum texto normativo que entraria em conflito com ela. Para evitar isso e garantir a supremacia constitucional, começou a ser aceito que o Judiciário fizesse um controle de constitucionalidade. Isso, ressalta-se, não era previsto na Constituição dos Estados Unidos. “[...] O controle jurisdicional da constitucionalidade das leis no EUA resulta de uma construção pretoriana [...]”. (Mendes; Branco, 2011, p. 57)

Percebe-se, portanto, que a Revolução Francesa e a Independência dos Estados Unidos são de suma importância para o entendimento e compreensão do surgimento e evolução do constitucionalismo moderno. O Brasil, deve-se ressaltar, seguiu o modelo norteamericano, ou seja, foi adotado a noção da superioridade da Constituição. Todavia, em alguns momentos da história, como na Ditadura Militar, o texto normativo supremo era mera "carta

\footnotetext{
${ }^{12}$ Sobre a desconfiança do Legislativo na época da independência norte-americana, ensina Gilmar Mendes e Paulo Gonet: "A desconfiança para com o parlamento pode ser retraçada aos fatores desencadeadores da independência americana. Leis britânicas das vésperas da independência, em especial no que tange à taxação, provocaram a indignação dos colonos, que as viram como resultado de um parlamento corrompido, que se arrogara poder ilimitado. O Parlamento britânico se assomou aos colonos como força hostil à liberdade. A nova nação deveria precatar-se contra a legislatura propensa às medidas tirânicas. Haveria de se construir um governo limitado". (MENDES; BRANCO, op. cit., p. 56.)
} 
de papel", não vinculando os atos de quem detinha o poder, como será analisado no tópico seguinte.

\subsubsection{Evolução constitucional no Brasil e o Neoconstitucionalismo}

Atualmente, quando um estudante de direito começa a cursar a cadeira de Direito Constitucional, uma de suas primeiras lições é em relação a Supremacia da Constituição. Este estudante aprende que referido documento está no topo do ordenamento jurídico e todas as leis devem observá-lo para ter eficácia. Mas será que foi sempre assim? Será que a Constituição brasileira sempre foi respeitada e observada como é hoje?

Para responder essas perguntas, é necessário fazer uma digressão histórica com o intuito de apresentar a evolução do constitucionalismo brasileiro. Como já foi dito, o constitucionalismo pode ser divido em dois períodos: pré e pós Constituição de 1988. Com o advento desta Carta, o Brasil descobriu realmente o que é a Supremacia Constitucional, além do crescente respeito ao Poder Judiciário, principalmente ao Supremo Tribunal Federal, guardião da Constituição.

Contudo, antes da promulgação da Carta de 1988, o país viveu em momentos de grande instabilidade política, tendo, constantemente, rupturas de paradigmas, ou seja, uma alternância entre democracia e ditadura. Para se ter uma ideia, a atual Constituição, formalmente falando, é a sétima a ser implantada, desde a independência. ${ }^{13}$

Devido a essa instabilidade e ao fato do Brasil, em boa parte de sua história, ter sido regido por governos ditatoriais, pode-se considerar que o Neoconstitucionalismo, marcado pelo pensamento pós-positivista, é um movimento tardio no Direito Constitucional brasileiro, porquanto Alemanha, Itália - principais referências $-{ }^{14}$ Portugal e Espanha já experimentaram essa reformulação logo depois da Segunda Guerra Mundial (entre as décadas 50 e 70 do século XX).

\footnotetext{
${ }^{13}$ Antes da Constituição de 1988, o Brasil teve as Constituições de 1824, 1891, 1934, 1937 e 1967. Boa parte dos doutrinadores, como Bernardo Gonçalves Fernandes, defendem a posição de que a Emenda Constitucional n 01 de 1969 pode, no sentido material, ser considerada uma Constituição, haja vista o seu texto alterar grande parte da Carta de 1967.

14 “A principal referência no desenvolvimento do novo direito constitucional é a Lei Fundamental de Bonn (Constituição alemã), de 1949, e, especialmente, a criação do Tribunal Constitucional Federal, instalado em 1951. A partir daí teve início uma fecunda produção teórica e jurisprudencial, responsável pela ascensão científica do direito constitucional no âmbito dos países de tradição romano-germânica. A segunda referência de destaque é a da Constituição da Itália, de 1947, e a subseqüente instalação da Corte Constitucional, em 1956". (BARROSO, Luís Roberto. Neoconstitucionalismo e Constitucionalização do Direito (O Triunfo Tardio do Direito Constitucional no Brasil). Revista Eletrônica sobre a Reforma do Estado (RERE), Salvador, Instituto Brasileiro de Direito Público, $\mathrm{n}^{\circ}$. 9, março/abril, maio, 2007. Disponível em: < http://www.direitodoestado.com/revista/RERE-9-MAR\%C7O-2007-LUIZ\%20ROBERTO\%20BARROSO.pdf>. Acesso em: 20 jun. 2012.

Revista de Teorias da Democracia e Direitos Políticos le-SSN: 2525-9660| Curitiba | v. 2 | n. 2 | p. 76 - $97 \mid$
} 
Juiz, Agente Político ou Servidor Público? Análise Crítica da Natureza Jurídica da Função Jurisdicional a Partir do Constitucionalismo Moderno e do

Ativismo Judicial

Durante esse período, o Brasil vivia sob a ditadura instaurada pelos militares. A Constituição era uma mera carta de retórica, não tendo força para influenciar o sistema jurídico. Destarte, pode-se concluir que, formalmente, o referido documento estava no topo do ordenamento jurídico, mas, materialmente, não tinha força vinculante, muito menos rigidez. Eram mais observados e, por conseguinte, tinham mais credibilidade os atos normativos, dentre eles, os Atos Institucionais, elaborados pelo Presidente da República. Com isso, comprova-se que não havia, a rigor, um Estado de Direito, onde o poder é controlado e limitado pelo Direito, mas um Direito do regime militar.

Com o avento da Carta de 1988, houve uma forte influência das ideias neoconstitucionalistas no sistema jurídico brasileiro, acarretando em uma nova forma de vêla. O texto constitucional não era mais visto com um conjunto de diretrizes políticas, podendo ser violado pelo Legislativo e Executivo, como ocorria anteriormente. A sua força normativa e vinculante passaram a ser reconhecidas acarretando na gênese de mecanismos que impediam a elaboração de leis e atos normativos que fossem de encontro aos seus preceitos. ${ }^{15}$

Ao analisar o Neoconstitucionalismo, percebe-se que suas características, conforme Ana Paula de Barcellos, podem ser agrupadas em dois grupos: metodológico-formal e material. (Barcellos, 2005, p. 2 e ss) O primeiro grupo traz como características, com consequências lógicas, a normatividade da Constituição, ou seja, esse documento passa a ser reconhecido como um conjunto de normas que devem ser observadas, porquanto possuem imperatividade, que decorre da superioridade da Constituição. Por estar no topo do ordenamento jurídico e por desempenhar um papel importante no estabelecimento das diretrizes que os ramos do Direito devem seguir, a Carta de 1988 passou a ter um papel central no sistema jurídico brasileiro. Por isso, a última característica do grupo metodológicoformal é a centralidade da Constituição.

Em relação ao ponto de vista material, a autora estabelece duas principais características. A primeira consiste na promoção da dignidade da pessoa humana (art. $1^{\circ}$, III, CF) e dos Direitos Fundamentais, valores incorporados pelo texto constitucional; e a expansão de conflitos dentro do sistema constitucional. (Barcellos, 2005, p. 3 e 4)

\footnotetext{
${ }^{15}$ Sobre a força normativa da Constituição, ensina Luís Roberto Barroso que "[...] Atualmente, passou a ser premissa do estudo da Constituição, o reconhecimento de sua força normativa, do caráter vinculativo e obrigatório de suas disposições. Vale dizer: as normas constitucionais são dotadas de imperatividade, que é atributo de todas as normas jurídicas, e sua inobservância há de deflagrar os mecanismos próprios de coação, de cumprimento forçado. [...]”. (BARROSO, op. cit., 2007, p. 6).
} 
Como se observa, o modo de tratar, respeitar e observar a Constituição deu uma guinada em pouco tempo. Antes, como foi apresentado, ela era mera carta retórica, com pouca influência e quase nenhuma força. Com a promulgação da Carta de 1988, passou a repudiar a arbitrariedade dos governantes; começou a ser vista como uma norma superior, a qual todos devem respeitá-la; as interpretações de atos normativos são feitas, direta ou indiretamente, dependendo de suas localizações; os Direitos Fundamentais, antes desprezados pelos ditadores, e localizados ao final do documento, passou a ter posição de destaque.

Portanto, com o advento das noções pós-positivistas, representadas pelos ideais neoconstitucionalistas, as diretrizes estabelecidas pela Constituição não podem mais ficar no plano abstrato, muito menos serem desrespeitadas. Para evitar, ou minimizar ao máximo, foram criados mecanismos de controle que ficaram a cargo do Judiciário. Devido a isso, e com o intuito de proteger e efetivar as propostas elaboradas pela Constituição, os juízes começaram a ter uma posição ativista, interferindo-se em outras esferas, como o Legislativo e o Executivo, o que não era aceito até pouco tempo, haja vista ser uma grande afronta à Separação dos Poderes, tema que será melhor estudado no próximo tópico.

\section{ATIVISMO JUDICIAL E JUDICIALIZAÇÃO}

Como foi apresentado no tópico anterior, o constitucionalismo mundial e brasileiro passou por grandes mudanças. Até a Segunda Guerra Mundial, a Constituição era vista como uma carta política a qual tinha a intenção de lançar diretrizes que poderiam ser ou não seguidas pelo Legislador. O positivismo jurídico imperava na ciência do direito e o Direito era equiparado à lei. (Barroso, 2007, p. 4) Isso acabou justificando inúmeras atrocidades praticadas contra homossexuais, negros, deficientes mentais, portadores de necessidades especiais e, mormente, judeus.

Com o fim da guerra e com o escancaramento de todos os atos atrozes praticados pelos nazistas, constatou-se que havia a necessidade de ser alterado o método de se ver o direito. A Dignidade da Pessoa Humana passou a ser reconhecida como um direito inerente a todo e qualquer ser humano, sendo desprezada a distinção de qualquer natureza. ${ }^{16} \mathrm{~A}$

\footnotetext{
${ }^{16}$ Esses ideais estão previstos na Declaração Universal dos Direitos Humanos, o qual afirma, em seu preâmbulo, que o " [...] desconhecimento e o desprezo dos direitos do Homem conduziram a atos de barbárie que revoltam a consciência da Humanidade e que o advento de um mundo em que os seres humanos sejam livres de falar e de crer, libertos do terror e da miséria, foi proclamado com a mais alta inspiração do Homem". Além disso, o referido documento, no art. $2^{\circ}$, dispõe que "Todos os seres humanos podem invocar os direitos e as liberdades Revista de Teorias da Democracia e Direitos Políticos le-SSN: 2525-9660| Curitiba | v. 2 | n. 2 | p. 76 - $97 \mid$
} 
Juiz, Agente Político ou Servidor Público? Análise Crítica da Natureza Jurídica da Função Jurisdicional a Partir do Constitucionalismo Moderno e do

Ativismo Judicial

Constituição deixou de ser uma mera carta retórica e o seu caráter normativo, superior, imperativo e central passou a ser reconhecido.

No Brasil, com a introdução das diretrizes do Neoconstitucionalismo, a Constituição não é mais qualquer documento, como era visto e tratado na Ditadura Militar, mas, sim, uma Carta que estabelece o Estado Democrático de Direito (art. $1^{\circ}$, caput, CF), prevê como um de seus fundamentos a Dignidade da Pessoa Humana (art. $1^{\circ}$, III, CF), dispõe um rol não taxativo de Direitos e Garantias Fundamentais (Título II) etc.

Constata-se, portanto, que a missão da Constituição de 1988 não é a das mais fáceis, haja vista a grande quantidade de objetivos, direitos e garantias previstos. Para que isso seja corretamente observado, é de suma importância o comprometimento das funções do poder (Executivo, Legislativo e Judiciário). Todavia, nos últimos tempos tanto o Executivo como o Legislativo entraram em uma profunda crise, marcada pela corrupção, ${ }^{17}$ falta de credibilidade de seus representantes, bem como na inércia da regulamentação de direitos previstos na Constituição. ${ }^{18}$

Para compensar isso, o Judiciário começou a adotar uma posição ativista, proferindo decisões que, em alguns casos, interferem na esfera das outras funções do poder. A posição ativista se deve aos princípios consagrados pela Constituição Federal de 1988, dentre eles o de que "a lei não excluirá da apreciação do Poder Judiciário lesão ou ameaça a direito" (art. $5^{\circ}$ XXXV, CF), justificando, destarte, a crescente judicialização, fenômeno diferente, embora seja complementar, do ativismo judicial, como será demonstrado nos tópicos seguintes.

\subsection{Judicialização}

A Constituição Federal de 1988 estabeleceu, como um de seus fundamentos, a cidadania (art. $1^{\circ}$, III, CF) sem conceituá-la adequadamente, o que gera algumas distorções em relação ao seu real significado. O equívoco surge a partir do momento em que o referido fundamento está atrelado apenas ao direito de votar e ser votado, porquanto isso é apenas um

proclamados na presente Declaração, sem distinção alguma, nomeadamente de raça, de cor, de sexo, de língua, de religião, de opinião política ou outra, de origem nacional ou social, de fortuna, de nascimento ou de qualquer outra situação. Além disso, não será feita nenhuma distinção fundada no estatuto político, jurídico ou internacional do país ou do território da naturalidade da pessoa, seja esse país ou território independente, sob tutela, autônomo ou sujeito a alguma limitação de soberania". (ORGANIZAÇÃO DAS NAÇÕES UNIDAS. Declaração Universal De Direitos Humanos. Comitê da Cultura de Paz. Disponível em: < http://www.comitepaz.org.br/download/Declara\%C3\%A7\%C3\%A3o\%20Universal\%20dos\%20Direitos\%20Hu manos.pdf>. Acesso em: 13 jul. 2012.)

${ }^{17}$ Um bom exemplo é a Ação Penal 470 que tramita no Supremo Tribunal Federal, mais conhecido como "Mensalão".

${ }^{18}$ Pode-se citar a falta de regulamentação da greve dos servidores público, garantido pelo art. 37, VII, CF. 
de seus desdobramentos. Cidadania está vinculada a algo maior, ou seja, a ideia de que o cidadão não é um simples eleitor, mas um detentor de direitos, um participante político, um fiscal que pode cobrar do Estado o cumprimento das normas estabelecidas. ${ }^{19}$

Contudo, não adianta declarar direitos do cidadão se não houver meios que os garantam, meios coercitivos os quais determinam que o Estado cumpra os deveres impostos pela Constituição. Para isso foram criados instrumentos capazes de garantir os direitos declarados pelo referido documento supremo. A título de exemplo, podem-se citar os remédios constitucionais, como o Habeas Corpus (art. 5, LXVIII, CF), o Mandado de Segurança (art 5 , LXIX e LXX, CF), o Mandado de Injunção (art. $5^{\circ}$, LXXI, CF), o Habeas Data (art. $5^{\circ}$, LXXII, CF) e a Ação Popular (art. $5^{\circ}$, LXXIII, CF).

Essas garantias permitem que os princípios do acesso à justiça e o da inafastabilidade jurisdicional sejam observados, possibilitando a configuração, bem como a consolidação da judicialização, que, nas palavras de Luís Roberto Barroso, “[...] significa que algumas questões de larga repercussão política ou social estão sendo decididas por órgãos do Poder Judiciário, e não pelas instâncias políticas tradicionais: o Congresso Nacional e o Poder Executivo". (2008, on line)

O referido fenômeno pode ser justificado por três fatores: a redemocratização; a constitucionalização abrangente; o controle de constitucionalidade. (Barroso, 2008, on line) No primeiro caso, além da cidadania, como já explicitado, deve-se ressaltar que os membros do Judiciário adquiriram garantias para poder exercer seu mister com independência e imparcialidade ${ }^{20}$ decidindo de acordo com suas convicções e conforme a lei, não precisando se submeter a pressões. Ademais, com a redemocratização, as garantias dadas ao Judiciário foram estendidas ao Ministério Público, que exerce função essencial à Justiça, "[...] incumbindo-lhe a defesa da ordem jurídica, do regime democrático e dos interesses sociais e

\footnotetext{
${ }^{19}$ Sobre o tema, é mister citar Francisco Gérson Marques de Lima, o qual afirma que "O cidadão não é mais o simples eleitor, nem o candidato de quem se vota. É o sujeito ativo, responsável pela história que o envolve, participante do fenômeno político, com direito e aptidões de participar das decisões do Estado, deste cobrando, exigindo e vindicando posturas e atitudes efetivas para a satisfação das necessidades e anseios sociais e individuais. A nova postura do cidadão coloca-o no status de censor, com poderes de fiscalizar a Administração Pública. (LIMA, Francisco Gérson Marques. Fundamentos Constitucionais do Processo: sob a perspectiva de eficácia dos direitos e garantias fundamentais. São Paulo: Malheiros, 2002, p. 99 - 100)

${ }^{20}$ Segundo José Afonso da Silva: "Aos órgãos jurisdicionais, consoante vimos, incumbe a solução dos conflitos de interesses, aplicando a lei aos casos concretos, inclusive contra o governo e a administração. Essa elevada missão, que interfere com a liberdade humana e se destina a tutelar os direitos subjetivos, só poderia ser confiada a um poder do Estado, distinto do Legislativo e do Executivo, que fosse cercado de garantias constitucionais de independência”. (SILVA, José Afonso. Curso de Direito Constitucional Positivo. 33. ed. São Paulo: Malheiros, 2010, p. 588.)

Revista de Teorias da Democracia e Direitos Políticos le-SSN: 2525-9660| Curitiba | v. 2 | n. 2 | p. 76 - $97 \mid$
} 
Juiz, Agente Político ou Servidor Público? Análise Crítica da Natureza Jurídica da Função Jurisdicional a Partir do Constitucionalismo Moderno e do

Ativismo Judicial

individuais indisponíveis" (art. 127, caput, CF). Por fim, deve-se, outrossim, citar a Defensoria Pública, órgão responsável pela “[...] orientação jurídica e a defesa, em todos os graus, dos necessitados [...]" (art. 134, caput, CF). Todos esses órgãos contribuem para que a cidadania seja exercida de forma plena.

A segunda causa está ligada com o fato da Carta de 1988 ser analítica, trazendo para o seu corpo matérias que não dizem respeito à organização do Estado. Isso se deve ao fato do constituinte originário achar necessário que determinados assuntos fossem protegidos pela Constituição, pois, além de ser uma norma que estabelece diretrizes para todo o ordenamento jurídico, é um documento rígido, ou seja, de difícil alteração, o que impossibilita a exclusão ou alteração de direitos facilmente. ${ }^{21}$ Por conseguinte, temas como a educação, a saúde, o trabalho, a moradia, o lazer, a segurança, a previdência social, a proteção à maternidade e à infância, direitos sociais previstos na Carta de 1988, poderão chegar ao conhecimento do Judiciário, que deverá debatê-los.

Por fim, tem-se o sistema de controle de constitucionalidade brasileiro, classificado pela doutrina como eclético, híbrido ou misto. (Barroso, 2009, p. 64) Esse sistema engloba tanto o controle incidental ou difuso, quanto o controle principal ou concentrado. O primeiro possibilita que todos os membros do Judiciário, não importando a entrância ou instância em que estejam, afastem a incidência de uma lei ou ato normativo pelo fato de ir de encontro com a Constituição. Já a segunda modalidade de controle possibilita que o Supremo Tribunal Federal analise em abstrato a lei ou ato normativo em face da Constituição Federal.

Este tipo de controle possibilita que o Supremo Tribunal Federal se manifeste acerca da constitucionalidade de leis que geraram grandes discussões, como, por exemplo, a Lei de Biossegurança (ADI 3510); análise da constitucionalidade da resolução ${ }^{\circ} 135$ do Conselho Nacional de Justiça (ADI 4638); Lei Maria da Penha (ADI 4424). Isso se deve ao fato de existirem vários legitimados ${ }^{22}$ para as ações que visam o controle de constitucionalidade (ação

\footnotetext{
${ }^{21}$ Para a Constituição ser aprovada, conforme dispõe o art. $60, \S 2^{\circ}$, da Constituição Federal, a proposta deverá ser "discutida e votada em cada Casa do Congresso Nacional, em dois turnos, considerando-se aprovada se obtiver, em ambos, três quintos dos votos dos respectivos membros". Ademais, existem matérias que não podem ser objetos de emenda constitucional como a forma federativa de Estado (art. $60, \S 4^{\circ}$, I, CF); o voto direto, secreto, universal e periódico (art. 60, $\S 4^{\circ}$, II, CF); a separação dos Poderes (art. 60, $\S 4^{\circ}$, III, CF); os direitos e garantias individuais (art. 60, $\S 4^{\circ}, \mathrm{IV}, \mathrm{CF}$ ).

${ }_{22} \mathrm{O}$ art. 103 da Constituição Federal dispõe o rol dos legitimados para propor a ação direta de inconstitucionalidade (ADI), ação direta de constitucionalidade por omissão (ADO), ação declaratória de constitucionalidade (ADC), arguição de descumprimento de preceito fundamental (ADPF). Nesse rol, estão presentes o Presidente da República (inciso I); a Mesa do Senado Federal (inciso II); a Mesa da Câmara dos Deputados (inciso III), a Mesa da Assembleia Legislativa ou da Câmara Legislativa do Distrito Federal (inciso
} 
direta de inconstitucionalidade (ADI), ação direta de constitucionalidade por omissão (ADO), ação declaratória de constitucionalidade (ADC), arguição de descumprimento de preceito fundamental (ADPF)).

Destarte, percebe-se que foram estabelecidos vários meios para provocar o Judiciário, que possui a obrigação de apreciar o caso, possibilitando que juízes profiram decisões políticas de forma que acabam invadindo a esfera dos outros Poderes (Legislativo e Executivo). Esse tema será objeto de estudo do próximo tópico.

\subsection{Ativismo Judicial}

A judicialização, como visto anteriormente, fez com que barreiras impeditivas de um maior acesso à atividade jurisdicional fossem extintas ou minimizadas. Isso gerou algumas consequências pragmáticas, porquanto temas, antes decididos apenas pelos poderes Legislativo e Executivo, começaram a ser reconhecidos e solucionados pelo Judiciário. A posição progressista desta função do poder possibilitou a ampliação do alcance das normas constitucionais, pois a Constituição Federal começou a ser interpretada de maneira extensiva. Esse fenômeno é denominado de ativismo judicial.

Segundo Luís Roberto Barroso, o ativismo judicial, expressão gerada nos Estados Unidos, pode se manifestar por meio das seguintes condutas:

[...] (i) a aplicação direta da Constituição a situações não expressamente contempladas em seu texto e independentemente de manifestação do legislador ordinário; (ii) a declaração de inconstitucionalidade de atos normativos emanados do legislador, com base em critérios menos rígidos que os de patente e ostensiva violação da Constituição; (iii) a imposição de condutas ou de abstenções ao Poder Público, notadamente em matéria de políticas públicas. (Barroso, 2008, p. 5)

Constata-se que o ativismo judicial posiciona o Judiciário no centro das discussões de temas relevantes, haja vista ser ele o detentor da última palavra. Ademais, o referido fenômeno possibilita que os membros dos Poderes Legislativo e Executivo, que assumem os seus cargos por meio de eleições periódicas, não se desgastem politicamente em discussões polêmicas $^{23}$ (o caso do aborto de feto anencéfalo, da liberação do uso da maconha, da

IV); o Governador de Estado ou do Distrito Federal (inciso V); o Procurador-Geral da República (inciso VI); o Conselho Federal da Ordem dos Advogados do Brasil (inciso VII); partido político com representação no Congresso Nacional (inciso VIII); confederação sindical ou entidade de classe de âmbito nacional (inciso IX).

${ }^{23}$ Isso demonstra que a crise institucional do Legislativo, provocada, outrossim, por sucessivas denúncias de corrupção, tem feito com que o Judiciário se expanda, como leciona Luís Roberto Barroso: “[...] Nos últimos anos, uma persistente crise de representatividade, legitimidade e funcionalidade no âmbito do Legislativo tem alimentado a expansão do Judiciário nessa direção, em nome da Constituição, com a prolação de decisões que suprem omissões e, por vezes, inovam na ordem jurídica, com caráter normativo geral". (BARROSO, op. cit., 2008, p. 7).

Revista de Teorias da Democracia e Direitos Políticos le-SSN: 2525-9660| Curitiba | v. 2 | n. 2 | p. 76 - $97 \mid$ 
Juiz, Agente Político ou Servidor Público? Análise Crítica da Natureza Jurídica da Função Jurisdicional a Partir do Constitucionalismo Moderno e do

Ativismo Judicial

$\overline{\text { regulamentação do casamento homossexual, por exemplo), }{ }^{24} \text { porquanto o modo de investidura }}$ dos magistrados é diferente dos outros poderes (aprovação em concurso público ou nomeação, nos casos dos Tribunais de Justiça e Regionais, além dos Tribunais Superiores, incluindo o STF), bem como os membros do Judiciário possuem, como já ressaltado, garantias constitucionais que têm o fito de promover a imparcialidade e a independência, podendo proferir decisões que protegem a Constituição Federal e, consequentemente, todos os cidadãos, sem receio de sofrer represálias.

O ativismo judicial tem origem nos Estados Unidos, quando a Suprema Corte deixou de proferir decisões conservadoras, optando por não interferir na esfera dos outros Poderes (autocontenção judicial) $^{25}$ e começou a decidir casos polêmicos (hard cases), produzindo jurisprudência envolvendo negros, privacidade, aborto e processo penal. (Barroso, 2008, p. 6) Seguindo essa mesma linha, o Judiciário brasileiro também começou a proferir decisões do mesmo tipo, como as cotas para universidade (ADPF 186), casos em que envolvem o sistema de saúde, pneus usados (ADPF 101), dentre outros.

Por fim, deve-se frisar que mesmo sendo necessário no atual cenário jurídico-político brasileiro, devido a intensa crise que se instaurou dentro do Legislativo e Executivo, ${ }^{26}$ decisões ativistas devem ser proferidas apenas em casos difíceis, ${ }^{27}$ que necessitem de uma

\footnotetext{
${ }^{24}$ Arguição de Descumprimento de Preceito Fundamental (ADPF) n ${ }^{\circ}$ 54. Nesse caso, ficou decidido pela maioria do plenário que a interrupção de gestação de feto anencéfalo não configura o delito tipificado nos arts. 124, 126 e 128, I e II, do Código Penal.

${ }^{25}$ Sobre autocontenção judicial, afirma Luís Roberto Barroso: "O oposto do ativismo é a auto-contenção judicial, conduta pela qual o Judiciário procura reduzir sua interferência nas ações dos outros Poderes. Por essa linha, juízes e tribunais (i) evitam aplicar diretamente a Constituição a situações que não estejam no seu âmbito de incidência expressa, aguardando o pronunciamento do legislador ordinário; (ii) utilizam critérios rígidos e conservadores para a declaração de inconstitucionalidade de leis e atos normativos; e (iii) abstêm-se de interferir na definição das políticas públicas. Até o advento da Constituição de 1988, essa era a inequívoca linha de atuação do Judiciário no Brasil. A principal diferença metodológica entre as duas posições está em que, em princípio, o ativismo judicial procura extrair o máximo das potencialidade do texto constitucional, sem contudo invadir o campo da criação livre do Direito. A auto-contenção, por sua, vez, restringe o espaço de incidência da Constituição em favor das instâncias tipicamente políticas". (BARROSO, op. cit., 2008, p. 6).

${ }^{26}$ A referida crise já é tão profunda, que muitas vezes as pessoas associam o político a pessoa corrupta, que só tem interesse em chegar a "representar o povo" para desviar verbas públicas ou evitar que suas empresas, aplicações e qualquer outra forma de renda, sejam fiscalizadas. Infelizmente, grande parte dos representantes não possui ou não apresentam mais ideologias políticas.

${ }_{27}$ É mister citar Thiago Magalhães Pires, que ao criticar a falta de limites ao Judiciário afirma: "Diante de tudo o que se acaba de ver, a única conclusão a que se pode chegar é que esse quadro é insustentável. Os juízes não são necessariamente mais sábios, conscientes ou informados que o resto das pessoas. Além disso, como seres humanos mortais, estão sujeitos às mesmas falhas de caráter que os demais - inclusive os agentes políticos eleitos: os escândalos de corrupção estão longe de se restringirem ao Executivo e ao Legislativo. Sem dúvida, a justiça deve ser perseguida. Mas nada garante que o Judiciário conseguirá alcançá-la. Ou que está mais aparelhado que os demais para fazê-lo". (PIRES, Thiago Magalhães. Pós-positivismo sem trauma: o possível e o indesejável no reencontro do direito com a moral. In: FELLET, André Luiz Fernandes; PAULA, Daniel Giotti de; NOVELINO, Marcelo (Org.). As novas faces do Ativismo Judicial. Salvador: JusPodivm, 2011, p. 51.).
} 
intensa discussão teórica e jurídica, além da participação ampla da sociedade, por meio do amicus curie ${ }^{28}$ evitando que as decisões dos magistrados da Suprema Corte não sejam proferidas com subjetividade e discricionariedade. (Barroso, 2011, p. 227) Ademais não se pode deixar a largo da discussão, que o Judiciário é um poder que tem função tipicamente judicante e não legiferante. Destarte, surge o temor de que, no momento em que os magistrados adotam uma posição ativista, estejam indo de encontro com o princípio da separação dos Poderes. Para ilustrar isso, cita-se a súmula vinculante $n^{\circ} 13$. Nesse caso, o Supremo Tribunal Federal fez um sopesamento de princípios, o que é inconcebível, haja vista o referido método ser utilizado para produção de textos normativos, função do Legislativo. ${ }^{29}$

Portanto, o ativismo pode gerar um atentado ao princípio da separação dos Poderes, porquanto o Judiciário acaba legislando positivamente, ou seja, cria regras, que não é sua função. Devido a isso, indaga-se se os membros do Judiciário são agentes políticos ou servidores públicos, que será respondida no próximo capítulo.

\section{JUIZ, AGENTE POLÍTICO OU SERVIDOR PÚBLICO?}

Conforme argumentos apresentados, a Constituição Federal de 1988, com o intuito de garantir o exercício do direito de cidadania, além de observar os vários Direitos Fundamentais, determinou que o Judiciário apreciasse todas as causas a ele submetidas, devendo dar uma solução ao conflito. Isso proporcionou ao Judiciário a oportunidade de proferir decisões, baseadas nos princípios constitucionais, bem como a utilização da interpretação extensiva, que invadisse as atribuições do Legislativo e do Executivo. Por

\footnotetext{
${ }^{28}$ A possibilidade de o Supremo Tribunal Federal admitir a manifestação de outros ou entidades sobre o tema é previsto no art. $7, \S 2^{\circ}$ da Lei $n^{\circ}$ 9868/99. Como exemplo, pode-se citar a audiência pública que reuniu especialistas para apresentar argumentos em relação a Lei de Biossegurança, objeto da Ação Direta de Inconstitucionalidade (ADI) 3510.

${ }^{29}$ Sobre o tema, cita-se Virgílio Afonso da Silva, o qual dispõe que “[...] Há casos - e esses são a maioria - em que a restrição a um direito fundamental é veiculada por meio de regra presente em um texto normativo infraconstitucional. Esse tipo de restrição [...] ocorre sempre que o legislador, em determinada situação, se vê obrigado a fazer um sopesamento entre dois ou mais princípios, cujo resultado, então, é expresso pela regra infraconstitucional. Essa é uma tarefa central da legislação ordinária. Esse resultado do sopesamento do legislador - que pode ser, por exemplo, um dispositivo de direito civil, de direito penal, de direito tributário ou de direito de trabalho - pode, em um sistema em que há jurisdição constitucional, como é o caso do Brasil ser questionado judicialmente. Nesse processo de controle de constitucionalidade da lei, se houver uma restrição a direito fundamental, deve-se recorrer à regra da proporcionalidade, nos moldes analisados anteriormente: ou seja, deve-se indagar se a regra infraconstitucional que restringe um direito fundamental é adequada para fomentar seus objetivos (fomentar a realização de um outro direito fundamental, por exemplo), se não há medida alternativa tão eficiente quanto, mas menos restritiva, e, por fim, se há um equilíbrio entre a restrição de um direito e a realização de outro". (SILVA, Virgílio Afonso da. Direito Fundamentais: conteúdo essencial, restrições e eficácia. 2. ed. São Paulo: Malheiros, 2011, p. 178 - 179.)

Revista de Teorias da Democracia e Direitos Políticos le-SSN: 2525-9660| Curitiba | v. 2 | n. 2 | p. 76 - 97|
} 
Juiz, Agente Político ou Servidor Público? Análise Crítica da Natureza Jurídica da Função Jurisdicional a Partir do Constitucionalismo Moderno e do

Ativismo Judicial

conseguinte, pode-se afirmar que o Judiciário profere decisões de cunho político, gerando discussões doutrinárias acerca da natureza dos magistrados, ou seja, se eles são servidores públicos ou agentes políticos.

A doutrina administrativa é dividida em relação a essa classificação, pois antes da Constituição Federal de 1988 o juiz era um mero aplicador do direito, devendo abstrair-se e afastar-se dos seus sentimentos ao julgar os casos apresentados. ${ }^{30}$ Alguns doutrinadores, como Celso Antônio Bandeira de Mello, (2010, p. 247 e ss) José dos Santos Carvalho Filho (2011, p.538 e ss) e Maria Sylvia Zanella di Pietro, (2010, p. 512 e ss) afirmam que eles são servidores públicos. Já Hely Lopes Meirelles (2010, p.77 e ss) e o Supremo Tribunal Federal, ${ }^{31}$ conforme análise de sua jurisprudência, defendem a posição de que os juízes são agentes políticos.

Para entender o motivo dessa divergência, deve-se procurar saber como cada um conceitua agente político. O primeiro grupo (defensores de que os membros do Judiciário são servidores públicos) afirma que agente político é aquele que possui a titularidade de cargo estrutural à organização política do país, (Mello, 2010, p. 247) além de elaborarem estratégias políticas necessárias para que o Estado atinja os seus fins. (Carvalho Filho, 2011, p. 538) Portanto, são agentes políticos os membros do Poder Executivo (Presidente da República, Governadores e Prefeitos), seus auxiliares (Ministros de Estado e Secretários Municipais e Estaduais) e os membros do Poder Legislativo. (Carvalho Filho, 2011, p. 538)

Já o segundo grupo estende a compreensão do conceito de agente político. Para ele, a referida classificação alberga os agentes que possuem "plena liberdade funcional, desempenhando suas atribuições com prerrogativas e responsabilidades próprias,

\footnotetext{
${ }^{30}$ Graciliano Ramos, em seu romance, demonstra claramente que o juiz não poderia apresentar opiniões ou interpretações diversa do que a lei dava. Para isso, ele deveria afastar todos os seus sentimentos aplicar a lei como se fosse uma máquina. (RAMOS, Graciliano. São Bernardo. 70. ed. Rio de Janeiro: Record, 2000, p. 65.” ${ }^{31}$ Acerca da posição adotada pelo Supremo Tribunal Federal, é mister analisar a referida jurisprudência: "Recurso extraordinário. Responsabilidade objetiva. Ação reparatória de dano por ato ilícito. Ilegitimidade de parte passiva. 2. Responsabilidade exclusiva do Estado. A autoridade judiciária não tem responsabilidade civil pelos atos jurisdicionais praticados. Os magistrados enquadram-se na espécie agente político, investidos para o exercício de atribuições constitucionais, sendo dotados de plena liberdade funcional no desempenho de suas funções, com prerrogativas próprias e legislação específica. 3. Ação que deveria ter sido ajuizada contra a Fazenda Estadual - responsável eventual pelos alegados danos causados pela autoridade judicial, ao exercer suas atribuições -, a qual, posteriormente, terá assegurado o direito de regresso contra o magistrado responsável, nas hipóteses de dolo ou culpa. 4. Legitimidade passiva reservada ao Estado. Ausência de responsabilidade concorrente em face dos eventuais prejuízos causados a terceiros pela autoridade julgadora no exercício de suas funções, a teor do art. 37, $\S 6^{\circ}$, da CF/88. 5. Recurso extraordinário conhecido e provido. (STF, RE 228977/SP, Rel. Ministro Néri da Silveira, 2. T., julgado em 05.03.2002, DJU de 12.04.2002, p. 66.)
} 
estabelecidas na Constituição e em leis especiais". (Meirelles, 2010, p. 77) Portanto, os membros do Judiciário fazem parte dessa classificação.

Com todas as vênias à primeira linha e reconhecendo o seu mérito, pensa-se que essa classificação não se adéqua mais ao atual contexto jurídico-político brasileiro, pois ela pertence ao tempo de que o juiz era, apenas, um mero aplicador do direito, exercendo uma função mecânica. Contudo com a Constituição Federal de 1988 e a declaração de todos os direitos e garantias já desenvolvidos neste trabalho, os magistrados passaram a proferir decisões de cunho político. Basta observar jurisprudências de tribunais que determinam a distribuição de remédios, os toques de recolher determinando que crianças e adolescentes regressem em hora previamente determinadas para as suas residências. Ademais, não se pode deixar ao largo da discussão a possibilidade que a Constituição Federal deu aos magistrados de legislar positivamente. Isso pode ser facilmente constatado ao se analisar a finalidade do mandado de injunção e da Ação Direta de Inconstitucionalidade por omissão (ADO).

A Carta de 1988, conquanto seja analítica, não regulamentou todos os seus dispositivos, deixando essa tarefa para o legislador ordinário. Contudo, em alguns casos, o legislador continua inerte, não regulamentando o direito disposto no texto constitucional. A Constituição, prevendo essa possibilidade, criou os referidos mecanismos para que o direito não seja mitigado. Assim, o Judiciário poderá regulamentá-los temporariamente, ou seja, enquanto o órgão legiferante não elabora lei que regule devidamente o direito. ${ }^{32}$ Portanto, há uma clara interferência do Judiciário na esfera de atuação do Legislativo, sendo isso permitido pela própria Constituição, isto é, este documento relativiza o princípio da separação dos Poderes (art. $2^{\circ}, \mathrm{CF}$ ), pois há um interesse maior de que os direitos declarados sejam observados, respeitados e regulamentados.

Portanto, com tudo o que exposto, constata-se que o Judiciário não é apenas um mero aplicador da lei posta. Ele ultrapassou essa barreira, chegando ao ponto de determinar que o

\footnotetext{
32 À míngua de regulamentação do dispositivo referente ao mandado de injunção não há especificação do procedimento a ser adotado em juízo, o que tem levado a adotar, por analogia, o do mandado de segurança. Quando à decisão a ser tomada nele, tem-se entendido que, em se tratando de órgão administrativo, basta que se lhe dê prazo para agir suprindo a falta dentro de trinta dias. Mas, em se tratando de órgão legislativo - Casas do Congresso Nacional -, que apenas se lhe dê ciência para as providências que possam caber. Solução que, evidentemente, na grande maioria das situações não leva a nada. É necessário romper com essa postura imobilista, fazendo os juízes o que deles se espera, ou seja, adotando a regra que adotariam se fossem legisladores. Não parece que essa providência poderia ser entendida como intromissão nos assuntos de outro poder, mas, sim, caso de cumprimento da Constituição. (FERRAZ FILHO, José Francisco Cunha. Art. $5^{\circ}$. In: MACHADO, Antônio Cláudio da Costa (Org.); FERRAZ, Anna Candida da Cunha (Coord.). Constituição Federal Interpretada: artigo por artigo, parágrafo por parágrafo. Barueri: Manole, 2010, p. 47.).

Revista de Teorias da Democracia e Direitos Políticos le-SSN: 2525-9660| Curitiba | v. 2 | n. 2 | p. 76 - 97|
} 
Juiz, Agente Político ou Servidor Público? Análise Crítica da Natureza Jurídica da Função Jurisdicional a Partir do Constitucionalismo Moderno e do Ativismo Judicial

Estado atue nas situações em que é omisso, como o caso dos Municípios fornecerem educação às crianças. O juiz não pode ser considerado um servidor público, mas um agente político, que profere decisões políticas para que a Constituição Federal sempre seja respeitada.

\section{CONCLUSÃO}

O movimento constitucionalista sofreu grandes transformações ao longo da história da humanidade, mormente com a Revolução Francesa e com a independência dos Estados Unidos, que cunharam o conceito do constitucionalismo moderno, que estabelecia um Estado limitado pelo direito. No primeiro caso, em virtude das ideias elaboradas por Rousseau, o Parlamento passou a ser o órgão máximo, haja vista ser o representante do povo. Isso acarretou em algumas consequências: o Judiciário passou a ser um órgão que tinha a mera função de aplicar a lei ao caso concreto, não podendo, em hipótese alguma, declarar uma lei inconstitucional por dois motivos: primeiro, só quem podia exercer um controle de validade das leis era o órgão que a elaborava, portanto, o Parlamento; segundo, a Constituição era, apenas, uma Carta política, que não se encontrava no topo do ordenamento jurídico, pois tinha apenas a função de estabelecer as pretensões e organizar o Estado.

Já nos Estados Unidos, a Constituição passou a ser vista de outro modo, ou seja, como o documento supremo, dotado de força normativa e de imperatividade, devendo todo o ordenamento jurídico observá-la. Contudo, para que isso pudesse ser concretamente realizado, foi criado o controle de constitucionalidade, que ficou a cargo do Judiciário. Essa ideia foi tão forte, que ultrapassou as linhas do território dos Estados Unidos e chegou ao Brasil com a promulgação da primeira Constituição Republicana (1891). Todavia, os documentos constitucionais, salvo o de 1988, não tinham força normativa, quase não eram observados. No Brasil, devida as suas constantes rupturas políticas, o que valia eram as regras elaboradas por quem detinham o poder.

Isso foi alterado com a promulgação da Constituição Federal de 1988, que trouxe ao Brasil as ideias do Neoconstitucionalismo que já estavam sendo implementadas em outros países desde o fim da Segunda Guerra Mundial. Com o Neoconstitucionalismo, a Constituição passou a ser vista de outro modo, isto é, foi reconhecida a sua força normativa, a sua centralidade, a sua imperatividade e a sua superioridade. Contudo, para que essas novas 
características pudessem ser respeitadas, o Judiciário passou a ter um papel fundamental: o de proteger a Carta Suprema.

Para isso, direitos e garantias foram declarados pela Constituição, o que possibilitou que o Judiciário pudesse reconhecer todos os casos que são apresentados. Todavia, isso não foi o bastante, pois não adianta nada reconhecer se não puder dar soluções. Isso fez com que o Judiciário pudesse, sempre interpretando a Constituição, adotar uma posição ativista.

Não se pode pontuar o ativismo da atuação do Supremo Tribunal Federal como algo pejorativo, conforme esse vocábulo sugere, pelo simples fato de que o referido órgão judicante, no seu dia-a-dia, o que mais tem feito é assegurar os direitos fundamentais e pautarse de modo inflexível como um Tribunal defensor das liberdades públicas. Ademais, deve-se ter em mente de que a profunda crise que assola o Executivo e o Legislativo obriga o Judiciário a solucionar situações de competência das duas primeiras funções.

Isso se deve ao fato de que a Constituição deve ser sempre observada. Assim, o Judiciário, em alguns casos, interfere nas outras funções do Poder, proferindo decisões de cunho político. Portanto, conforme o que foi exposto, conclui-se que o magistrado não pode ser mais considerado um servidor público, como defende a doutrina clássica do direito administrativo, mas, sim, um agente político, que tem a obrigação de solucionar os conflitos que lhe são apresentados, devendo suas decisões sempre ser pautadas na Constituição.

\section{REFERÊNCIAS}

BARCELLOS, Ana Paula de. Neoconstitucionalismo, Direitos Fundamentais e Controle das Políticas Públicas. Mundo Jurídico, 2005. Disponível em: <http://www.mundojuridico.adv.br/cgi-bin/upload/texto853.pdf>. Acesso em: 20 jun. 2012

BARROSO, Luís Roberto. Constituição, democracia e supremacia judicial: direito e política no Brasil contemporâneo. In: FELLET, André Luiz Fernandes; PAULA, Daniel Giotti de; NOVELINO, Marcelo (Org.). As novas faces do Ativismo Judicial. Salvador: JusPodivm, 2011.

. Judicialização, Ativismo Judicial e Legitimidade Democrática. Migalhas, 2008.Disponível em: <http://www.migalhas.com.br/arquivo_artigo/art20090130-01.pdf>. Acesso em: 20 jun. 2012. 
Juiz, Agente Político ou Servidor Público? Análise Crítica da Natureza Jurídica da Função Jurisdicional a Partir do Constitucionalismo Moderno e do Ativismo Judicial Neoconstitucionalismo e Constitucionalização do Direito (O Triunfo Tardio do Direito Constitucional no Brasil). Revista Eletrônica sobre a Reforma do Estado (RERE), Salvador, Instituto Brasileiro de Direito Público, nº 9, março/abril, maio, 2007. Disponível em: $\quad<\quad$ http://www.direitodoestado.com/revista/RERE-9-MAR\%C7O-2007LUIZ\%20ROBERTO\%20BARROSO.pdf>. Acesso em: 20 jun. 2012.

O Controle de Constitucionalidade no Direito Brasileiro. 4. ed. São Paulo: Saraiva, 2009.

BONAVIDES, Paulo. Curso de Direito Constitucional. 25. ed. São Paulo: Malheiros, 2010. CARVAlHO FILHO, José dos Santos. Manual de Direito Administrativo. 24. ed. Rio de Janeiro: Lumen Juris, 2011.

COMPARATO, Fábio Konder. A afirmação histórica dos Direitos Humanos. 7. ed. São Paulo: Saraiva, 2010.

FERRAZ FILHO, José Francisco Cunha. Art. 5. In: MACHADO, Antônio Cláudio da Costa (Org.); FERRAZ, Anna Candida da Cunha (Coord.). Constituição Federal Interpretada: artigo por artigo, parágrafo por parágrafo. Barueri: Manole, 2010.

FERREIRA FILHO, Manoel Gonçalves. Curso de Direito Constitucional. 36. ed. São Paulo: Saraiva, 2010.

LIMA, Francisco Gérson Marques. Fundamentos Constitucionais do Processo: sob a perspectiva da eficácia dos direitos e garantias fundamentais. São Paulo: Malheiros, 2002.

LIMA, George Marmelstein. Curso de Direitos Fundamentais. 2. ed. São Paulo: Atlas, 2009.

MEIRELLES, Hely Lopes. Direito Administrativo Brasileiro. 36. ed. São Paulo: Malheiros, 2010.

MELlO, Celso Antônio Bandeira de. Curso de Direito Administrativo. 27. ed. São Paulo: Malheiros, 2010. 
MENDES, Gilmar Ferreira; BRANCO, Paulo Gustavo Gonet. Curso de Direito Constitucional. 6. ed. São Paulo: Saraiva, 2011.

ORGANIZAÇÃO DAS NAÇÕES UNIDAS. Declaração Universal De Direitos Humanos. Comitê da Cultura de Paz. Disponível em: < http://www.comitepaz.org.br/download/Declara\%C3\%A7\%C3\%A3o\%20Universal\%20dos\% 20Direitos\%20Humanos.pdf>. Acesso em: 13 jul. 2012.

PIETRO, Maria Sylvia Zanella di. Direito Administrativo. 23. ed. São Paulo: Atlas, 2010.

PIRES, Thiago Magalhães. Pós-positivismo sem trauma: o possível e o indesejável no reencontro do direito com a moral. In: FELLET, André Luiz Fernandes; PAULA, Daniel Giotti de; NOVELINO, Marcelo (Org.). As novas faces do Ativismo Judicial. Salvador: JusPodivm, 2011.

RAMOS, Graciliano. São Bernardo. 70. ed. Rio de Janeiro: Record, 2000.

SARLET, Ingo Wolfgang; MARINONI, Luiz Guilherme; MITIDIERO, Daniel. Curso de Direito Constitucional. São Paulo: Revista dos Tribunais, 2012.

SILVA, José Afonso. Curso de Direito Constitucional Positivo. 33. ed. São Paulo: Malheiros, 2010.

SILVA, Virgílio Afonso da. Direito Fundamentais: conteúdo essencial, restrições e eficácia. 2. ed. São Paulo: Malheiros, 2011.

TAVARES, André Ramos. Curso de Direito Constitucional. 9. ed. São Paulo: Saraiva, 2011. 